\title{
Continuing the progress at the Asia Pacific Journal of Management
}

\author{
David Ahlstrom
}

Published online: 6 October 2012

(C) Springer Science+Business Media New York 2012

It is with a sense of accomplishment that I am writing my last editorial as Editor-inChief of Asia Pacific Journal of Management, the position I have held since January of 2010, after having been senior editor since 2007. I followed Mike Peng of the University of Texas at Dallas, who was very instrumental, along with previous Chief Editors Andrew Delios and Kulwant Singh, both of the National University of Singapore (NUS), in making APJM an internationally recognized scholarly journal. Under their tutelage, APJM became the official journal of the Asia Academy of Management, a regional affiliate of the Academy of Management, and earned a listing on Thomson-ISI's Social Sciences Citation Index (SSCI). All of us interested in management and organizational research on the Asia Pacific region owe a lot to the work of these fine scholars and to $A P J M$ 's senior editors, editorial board members, reviewers, and authors for their hard work on the journal over these many years. During my tenure as editor, APJM has continued its growth and development. Submissions to the journal have more than doubled since 2009 and we have also increased the number of articles published in $A P J M$. The editorial team have all worked very hard to continue making $A P J M$ an important scholarly journal for authors and researchers interested in management and organizational studies in the Asia Pacific region.

Now, after nearly 3 years and over 1,500 reviewed manuscripts, I am happy to introduce our next Editor-in-Chief, Professor Michael (Mick) Carney of Concordia University in Montreal, who will start in 2013. Mick brings a great deal of experience to his editorship, as he has been associated with $A P J M$ in various capacities since the 1990s, and has served as a senior editor for the journal since 2007. Mick edited one APJM Special Issue and published nine articles in APJM since 1998 (e.g. Carney, 1998). The Special Issue that Mick ran in 2009 with our senior editors Eric Gedajlovic and Xiaohua Yang, "Varieties of Asian Capitalism: Indigenization and Internationalization," examined the important theme of varying business and

D. Ahlstrom $(\square)$

Department of Management, The Chinese University of Hong Kong, Shatin, NT, Hong Kong

e-mail: ahlstrom@baf.msmail.cuhk.edu.hk 
institutional systems in Asia (Carney, Gedajlovic, \& Yang, 2009). Mick has also worked on research on the Asia Pacific region ranging from in-depth case studies to, more recently, several interesting and important meta analyses (Carney, Gedajlovic, Huegens, van Essen, \& van Oosterhout, 2011; van Essen, van Oosterhout, \& Carney, 2012) the latter of which won the Mike Peng Best Paper Award from Springer, which is given annually to an excellent and recently published article in APJM. APJM will be in very capable and experienced hands with Mick and his editorial team.

\section{The growth of Asia (and Asia Pacific research)}

When I first started my business education in the mid-1980s, it was far from certain that Asia was at the dawn of a golden age. China had just emerged from decades of upheaval and slow economic growth. India was mired in slow growth; heavy-handed government interference in business and managed trade were common in most of the region. Poverty and Asia were inexorably linked in many people's minds as a majority of the world's poor lived in Asia. This is no longer true today as Asia has experienced steady and widely distributed economic growth and built successful and distinctive commercial cultures (Ahlstrom, Chen \& Yeh, 2010; Ahlstrom, Young, Chan, \& Bruton, 2004; Carney et al., 2009). In developing countries such as China and India hundreds of millions of people have left poverty and entered the middle class (Economist, 2009). No previous era of development, not that of Egypt or Imperial China at their heights, not the splendor of the Greco-Roman era, nor even the period following the Industrial Revolution, has approached the modern era of economic growth, particularly in Asia (Ahlstrom, 2010d; Maddison, 2007). China and India have emerged as major forces in the world economy; China is currently the world's second largest economy and, along with India and several other countries in Asia, continues to be among the world's fastest growing.

This economic growth has also yielded an increased interest in research in this region. Over the past decade or so, there has been a proliferation of new academic journals specializing in this part of the world, and an increasing number of researchers focusing on the Asia Pacific region. As economies in this region continue to occupy a more central position in the global economy, Asian management and organizational research will likely continue its growth (Ahlstrom et al., 2010; Fang, 2010; Meyer, 2006).

Growth at $A P J M$

APJM has experienced much change and growth over the past three decades as well. In 1983, APJM was founded at NUS as the first academic journal dedicated primarily to organizational research on the Asia Pacific region. APJM developed steadily under the management of longtime Chief Editor Kulwant Singh and his colleagues there, including former APJM editor Andrew Delios. The first issue in September of 1983 contained eight articles, one book review and one editor's note, covering 80 pages in total. APJM's most recent issue in September of 2012 (Volume 29, issue 3) was four times as large at 321 pages and 15 articles.

A major goal of my editorship has been to continue the fine work of past editors in making APJM one of the top academic management journals focused on the Asia 
Pacific region. As the end of 2012 approaches, and looking back at the past 3 years of effort, I am happy to say that with the unflagging help of our senior editors, reviewers, and authors, we have made a great deal of progress in building on the firm foundation provided by former Chief Editor Mike Peng and the previous editorial teams. By traditional measures, evidence is clear. The number of submissions to APJM rose from and 344 in 2009 to over 600 in 2011 with submissions expected to exceed 700 for 2012 - approximately two new manuscript submissions are received every day (see Fig. 1). Our acceptance rate, which was around 15 to $20 \%$ in past years, has dropped to less than $10 \%$ the past 2 years. Citations to the journal articles are up, and our impact factor from the Social Sciences Citation Index (SSCI) Journal Citation Reports has been over 3.0 each of the 2 years we have been on the Journal Citation Report (2011 and 2012). This places APJM up among the top 20 management and organizational journals near exceptional journals such as Personnel Psychology and the Journal of Business Venturing.

In addition to the fine senior editorial team at $A P J M$ and dedicated reviewers, a journal is also helped in its growth and development by a fine cadre of authors. Yuan Li, Executive Dean of the Antai College of Economics \& Management, Shanghai Jiaotong University has published with $A P J M$ on multiple occasions (e.g., Peng, Li, Xie, \& Su, 2010; Su, Li, Yang, \& Li, 2011), as has Dean Dan Shapiro of the Beedie School of Business, Simon Fraser University. Dean Shapiro coauthored a Special Issue on corporate governance in Asia in APJM in 2011 (Globerman, Peng, \& Shapiro, 2011). Other well-known scholors such as John Dunning (Dunning \& Lundan, 2008), Geert Hofstede (2007), Neal Ashkanasy (Li, Ashkanasy, \& Ahlstrom, 2010), Bob Liden (2012), Gordon Redding (Redding \& Witt 2009), Mike Hitt (Hitt, Lee, \& Yucel, 2002), Andy Van de Ven (2004), Ming-Jer Chen (2009, 2010), Mike Peng (Jiang \& Peng, 2011; Peng, 2005; Yang, Sun, Lin \& Peng, 2011; Zhou \& Peng, 2010) and many others - too numerous to mention - have published in APJM over the years.

But it should be emphasized that APJM also has an important mission of helping to develop new authors, particularly authors from the Asia Pacific region-a mission that we have carefully nurtured and developed. APJM regularly works with and publishes the work of new authors, many from countries that have not published much in English language academic journals. Indeed a good part of the increase in the

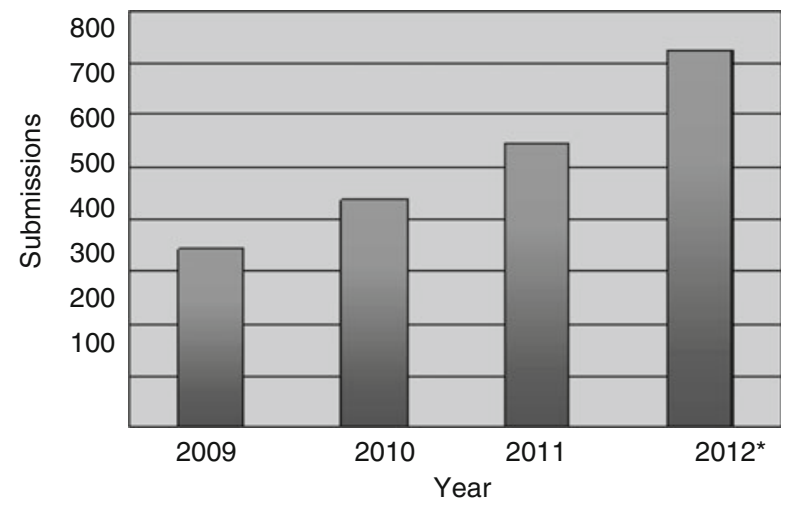

*Year's end estimate

Fig. 1 Manuscript submissions to the Asia Pacific Journal of Management, 2009-2012 
manuscript submissions to APJM have come from universities in China, India, and increasingly Central Asia, where research programs are ever more active. APJM editors have also worked hard to develop authors and their work by traveling to numerous conferences and workshops around Asia to train authors in writing and publishing management and organizational research (members of our editorial team have made about two dozen such trips around the Asia Pacific region during my tenure as $A P J M$ Chief Editor). At $A P J M$ we also make a strong effort to give authors guidance during the review and editing process and through the editorials, perspectives, and commentary articles we publish. Senior authors and regular contributors to APJM such as Ming-Jer Chen, Bob Liden, Mike Hitt, Garry Bruton, Chung-ming Lau, Mike Peng, Tony Fang, Klaus Meyer, and others have written and spoken much about their work to share important observations on their research programs and how authors might conduct research on these or related topics.

To provide further help to authors, particularly those fairly new to the field, I have also written nine editorial essays in APJM during my 2010-2012 editorial tenure on various basic research topics which also provide numerous helpful citations from the management and allied social sciences literature on research strategies and publishing in APJM. These editorial articles include avoiding common problems that lead to desk rejections (Ahlstrom, 2010b, c, 2012b), the different types of papers APJM typically publishes (Ahlstrom, 2010a, 2011a, 2012a) and approaches to paper organization (Ahlstrom, 2011b). Another editorial explained and summarized some of these articles and also provides additional resources for authors organized by topic and section of a paper, such as the literature review or the contributions section (Ahlstrom, 2011c). Many desk rejections could be avoided if authors were careful to read the editorials mentioned here and the various helpful works they cite (e.g., Abrahamson, 2008; Colquitt \& Ireland, 2009; Huff, 1999, 2008). Interested readers and prospective authors should check future issues of $A P J M$ for editorials and commentary papers which discuss research topics.

\section{The Mike Peng Best Paper Award}

With this issue, I am also pleased to announce the winners of the fifth Best Paper Award at APJM. The winners receive a US\$1,000 check, courtesy of our publisher, Springer. This year's Mike Peng Best Paper winner is - an excellent meta analysis on boards and Asian firm performance by van Essen et al. (2012): "Corporate boards and the performance of Asian firms: A meta-analysis." Previous winners include Kenneth Law, Chi-Sum Wong, Guo-Hua Huang, and Xiaoxuan Li, awarded in 2011, Mike Peng in 2010, John Matthews in 2009, and Klaus Meyer in 2008 (see Table 1). We thank Springer for their generosity and look forward to granting awards for the best papers in $A P J M$ in the coming years.

\section{Looking back and looking ahead}

I am very proud to have long been a part of the APJM team, from author and reviewer in the $1990 \mathrm{~s}$, to editorial board member, special issue editor, senior editor, Chief 


\title{
Announcing
}

\section{The Mike Peng Best Paper Award}

\author{
Awarded to \\ Marc van Essen \\ J. Hans van Oosterhout \\ Michael Carney \\ Corporate boards and the performance of Asian firms: \\ A meta-analysis
}

Asia Pacific Journal of Management 2012

\author{
Previous Best Paper Award Winners in Asia Pacific Journal of Management: \\ 2011 \\ Kenneth S. Law, Chi-Sum Wong, Guo-Hua Huang, Xiaoxuan Li (25(1): 51-69) \\ The effects of emotional intelligence on job performance and life \\ satisfaction for the research and development scientists in China \\ 2010 \\ Mike W. Peng (22(2): 123-141) \\ From China strategy to global strategy \\ 2009 \\ John A. Mathews (23(1): 5-27) \\ Dragon multinationals: New players in the $21^{\text {st }}$ century globalization \\ 2008 \\ Klaus E. Meyer (23(2): 119-137) \\ Asian management research needs more self-confidence
}

Editor, and after 2012, Consulting Editor. During my term as Chief Editor, we produced 12 issues and handled annual submissions that will likely exceed 700 in 2012. APJM's first 2 years on the SSCI have produced impact factors over 3. Under my editorship, APJM widened it's net in publishing some of its first experiments (e.g., Li, 2011; Li et al., 2010) meta analyses (e.g., van Essen et al., 2012), papers on the less-studied parts of Asia (in the management literature) including Central Asia (Ismail \& Ford, 2010), India (Lahiri, 2011), Iran (Soltani, Syed, Liao, \& ShahiSough, 2012), and the Ningxia Hui autonomous region of China (Cardoza \& Fornes, 2011), among others. APJM has also published on topics that are rather new to Asia research such as emotion (Law et al., 2008; Li, 2011; Li, Hui, Ashkanasy, \& Ahlstrom, 2012) and the negative effects of social exchange (Chen, Friedman, Yu, \& Sun, 2011; Lin \& Si, 2010). APJM has traditionally published papers using a range 
of research designs and from a range of research sites around the Asia Pacific region and looks forward to publishing innovative work and novel research sites in the coming years (e.g., Ahlstrom, Lamond, \& Ding, 2009; Dieleman 2010; Walsham, 2006). In closing, I want to thank the $A P J M$ and general management communities for their help in continuing to make the Asia Pacific Journal of Management an important scholarly journal that focuses primarily on building, testing, and extending management and organizational theory (and improving practice) in and on the Asia Pacific region (Ahlstrom, 2011a; Peng, 2009).

Acknowledgment The Asia Pacific Journal of Management would like to thank Rachel (Rae) Pinkham, Saraswathi "Sara" Sabapathy, and Jurgen Torres of Springer for their editorial and research assistance. Thanks are due to all of APJM's Senior Editors, the Editorial Advisory and Review Boards, our reviewers, and of course all of our authors for their hard work on behalf of the journal. Thanks also go out to Dean T.J. Wong of The Chinese University of Hong Kong, as well as Professor Garry Bruton and Dean Homer Erekson, of the Neeley School of Business, Texas Christian University, and Dean Daniel M. Shapiro of the Beedie School of Business, Simon Fraser University for their help and financial backing of APJM. And special thanks go to our former Editor-in-Chief Mike Peng of UT-Dallas for his unflagging support and assistance to APJM and our community of editors, reviewers, and authors.

\section{References}

Abrahamson, E. 2008. 22 things I hate: Mini rants on management research. Journal of Management Inquiry, 17(4): 422-425.

Ahlstrom, D. 2010a. Publishing in the Asia Pacific Journal of Management. Asia Pacific Journal of Management, 27(1): 1-8.

Ahlstrom, D. 2010b. Clearing the first hurdle at the Asia Pacific Journal of Management. Asia Pacific Journal of Management, 27(2): 171-177.

Ahlstrom, D. 2010c. Avoiding common missteps: Writing papers suitable for the Asia Pacific Journal of Management. Asia Pacific Journal of Management, 27(4): 583-586.

Ahlstrom, D. 2010d. Innovation and growth: How business contributes to society. Academy of Management Perspectives, 24(3): 10-23.

Ahlstrom, D. 2011a. On the aims and scope of the Asia Pacific Journal of Management: What does APJM really seek to publish?. Asia Pacific Journal of Management, 28(2): 215-219.

Ahlstrom, D. 2011b. A checklist for prospective authors of Asia Pacific Journal of Management. Asia Pacific Journal of Management, 28(3): 449-452.

Ahlstrom, D. 2011c. Some helpful sources for prospective authors in Asia Pacific Journal of Management. Asia Pacific Journal of Management, 28(4): 661-665.

Ahlstrom, D. 2012a. On the types of papers the Asia Pacific Journal of Management generally publishes. Asia Pacific Journal of Management, 29(1): 1-7.

Ahlstrom, D. 2012b. Several key reasons why a paper is likely to be rejected at the Asia Pacific Journal of Management. Asia Pacific Journal of Management, 29(3): 519-524.

Ahlstrom, D., Chen, S.-J., \& Yeh, K. S. 2010. Managing in ethnic Chinese communities: Culture, institutions, and context. Asia Pacific Journal of Management, 27(3): 341-354.

Ahlstrom, D., Lamond, D., \& Ding, Z. 2009. Reexamining some management lessons from military history. Asia Pacific Journal of Management, 26(4): 617-642.

Ahlstrom, D., Young, M. N., Chan, E. S., \& Bruton, G. D. 2004. Facing constraints to growth? Overseas Chinese entrepreneurs and traditional business practices in East Asia. Asia Pacific Journal of Management, 21(2): 263-285.

Cardoza, G., \& Fornes, G. 2011. The internationalisation of SMEs from China: The case of Ningxia Hui Autonomous Region. Asia Pacific Journal of Management, 28(4): 737-759.

Carney, M. 1998. A management-capacity constraint? Obstacles to the development of the Overseas Chinese family business. Asia Pacific Journal of Management, 15(2): 1-25. 
Carney, M., Gedajlovic, E. R., Huegens, P. P. M. A. R., van Essen, M., \& van Oosterhout, J. 2011. Business group affiliation, performance, context, and strategy: A meta-analysis. Academy of Management Journal, 54(3): 437-460.

Carney, M., Gedajlovic, E., \& Yang, X. 2009. Varieties of Asian capitalism: Toward an institutional theory of Asian enterprise. Asia Pacific Journal of Management, 26(3): 361-380.

Chen, M.-J. 2009. Competitive dynamics research: An insider's odyssey. Asia Pacific Journal of Management, 26(1): 5-25.

Chen, M.-J. 2010. Reflecting on the process: Building competitive dynamics research. Asia Pacific Journal of Management, 27(1): 9-24.

Chen, Y., Friedman, R., Yu, E., \& Sun, F. 2011. Examining the positive and negative effects of guanxi practices: A multi-level analysis of guanxi practices and procedural justice perceptions. Asia Pacific Journal of Management, 28(4): 715-736.

Colquitt, J. A., \& Ireland, R. D. 2009. From the editors: Taking the mystery out of AMJ's reviewer evaluation form. Academy of Management Journal, 52(2): 224-228.

Dieleman, M. 2010. Shock-imprinting: External shocks and ethnic Chinese business groups in Indonesia. Asia Pacific Journal of Management, 27(3): 481-502.

Dunning, J. H., \& Lundan, S. M. 2008. Institutions and the OLI paradigm of the multinational enterprise. Asia Pacific Journal of Management, 25(4): 573-593.

Economist. 2009. Burgeoning bourgeoisie: A special report on the new middle classes in emerging markets. Economist, 14: 1-14.

Fang, T. 2010. Asian management research needs more self-confidence: Reflection on Hofstede (2007) and beyond. Asia Pacific Journal of Management, 27(1): 155-170.

Globerman, S., Peng, M. W., \& Shapiro, D. M. 2011. Corporate governance and Asian companies. Asia Pacific Journal of Management, 28(1): 1-14.

Hitt, M. A., Lee, H.-U., \& Yucel, E. 2002. The importance of social capital to the management of multinational enterprises: Relational networks among Asian and Western firms. Asia Pacific Journal of Management, 19(2-3): 353-372.

Hofstede, G. 2007. Asian management in the 21st century. Asia Pacific Journal of Management, 24(4): 411-420.

Huff, A. S. 1999. Writing for scholarly publication. Thousand Oaks: Sage.

Huff, A. S. 2008. Designing research for publication. Thousand Oaks: Sage.

Ismail, K. M., \& Ford, D. L. 2010. Organizational leadership in Central Asia and the Caucasus: Research considerations and directions. Asia Pacific Journal of Management, 27(2): 321-340.

Jiang, Y., \& Peng, M. W. 2011. Principal-principal conflicts during crisis. Asia Pacific Journal of Management, 28(4): 683-695.

Lahiri, S. 2011. India-focused publications in leading international business journals. Asia Pacific Journal of Management, 28(2): 427-447.

Law, K. S., Wong, C.-S., Huang, G.-H., \& Li, X. 2008. The effects of emotional intelligence on job performance and life satisfaction for the research and development scientists in China. Asia Pacific Journal of Management, 25(1): 51-69.

Li, Y. 2011. Emotions and new venture judgment in China. Asia Pacific Journal of Management, 28(2): 277-298.

Li, Y., Ahlstrom, D., \& Ashkanasy, N. M. 2010. A multilevel model of affect and organizational commitment. Asia Pacific Journal of Management, 27(2): 193-213.

Li, Y., Hui, C., \& Ashkanasy, N. M. 2012. A multi-level study of emergent group leadership: Effects of emotional stability and group conflict. Asia Pacific Journal of Management, 29(2): 351366.

Liden, R. C. 2012. Leadership research in Asia: A brief assessment and suggestions for the future. Asia Pacific Journal of Management, 29(2): 205-212.

Lin, J., \& Si, S. X. 2010. Can guanxi be a problem? Contexts, ties, and some unfavorable consequences of social capital in China. Asia Pacific Journal of Management, 27(3): 561-581.

Maddison, A. 2007. Contours of the world economy 1-2030 AD: Essays in macro-economic history. Oxford: Oxford University Press.

Meyer, K. E. 2006. Asian management research needs more self-confidence. Asia Pacific Journal of Management, 23(2): 119-137.

Peng, M. W. 2005. From China strategy to global strategy. Asia Pacific Journal of Management, 22(2): $123-141$.

Peng, M. W. 2009. Passing the torch. Asia Pacific Journal of Management, 26(4): 611-616. 
Peng, M. W., Li, Y., Xie, E., \& Su, Z. 2010. CEO duality, organizational slack, and firm performance in China. Asia Pacific Journal of Management, 27(4): 611-624.

Redding, G., \& Witt, M. A. 2009. China's business system and its future trajectory. Asia Pacific Journal of Management, 26(3): 381-399.

Soltani, E., Syed, J., Liao, Y.-Y., \& Shahi-Sough, N. 2012. Tackling one-sidedness in equality and diversity research: Characteristics of the current dominant approach to managing diverse workgroups in Iran. Asia Pacific Journal of Management, 29(1): 9-37.

Su, Z., Li, J., Yang, Z., \& Li, Y. 2011. Exploratory learning and exploitative learning in different organizational structures. Asia Pacific Journal of Management, 28(4): 697-714.

Van de Ven, A. H. 2004. The context-specific nature of competence and corporate development. Asia Pacific Journal of Management, 21(1-2): 123-147.

van Essen, M., van Oosterhout, J. H., \& Carney, M. 2012. Corporate boards and the performance of Asian firms: A meta-analysis. Asia Pacific Journal of Management, 29(4). (this issue).

Walsham, G. 2006. Doing interpretative research. European Journal of Information Systems, 15: 320-330.

Yang, H., Sun, S. L., Lin, Z., \& Peng, M. W. 2011. Behind M\&As in China and the United States: Networks, learning, and institutions. Asia Pacific Journal of Management, 28(2): 239-255.

Zhou, J. Q., \& Peng, M. W. 2010. Relational exchanges versus arm's-length transactions during institutional transitions. Asia Pacific Journal of Management, 27(3): 355-370.

David Ahlstrom ( $\mathrm{PhD}$, New York University) is a professor at The Chinese University of Hong Kong. His research interests include managing in Asia, innovation and entrepreneurship, and management and organizational history. Professor Ahlstrom has published over 75 peer-reviewed articles in journals such as the Strategic Management Journal, Academy of Management Review, Journal of International Business Studies, Academy of Management Perspectives, and Organization Science. His work has also appeared on multiple occasions in The Wall Street Journal. Professor Ahlstrom co-authored the textbook International Management: Strategy and Culture in the Emerging World and guest edited two Special Issues of Entrepreneurship: Theory \& Practice. He also guest edited two Special Issues of APJM: Turnaround in Asia in 2004 and Managing in Ethnic Chinese Communities in 2010, and was APJM Senior Editor during 2007-2009, and Editor-in-Chief from 2010 to 2012. Professor Ahlstrom also spent several years in start-up firms in before entering academia. 